\title{
Antioxidant Compounds, Mineral Content and Antioxidant Activity of Several Tomato Cultivars Grown in Southwestern Romania
}

\author{
Violeta NOUR ${ }^{1 *}$, Ion TRANDAFIR ${ }^{2}$, Mira E. IONICA ${ }^{1}$ \\ ${ }^{1}$ University of Craiova, Department of Horticulture and Food Science, 13 A.I.Cuza Street, \\ 200585, Craiova, Romania; vionour@central.ucv.ro ( ${ }^{*}$ corresponding author) \\ ${ }^{2}$ University of Craiova, Department of Chemistry, 107 Calea Bucuresti Street, 200529, Craiova, Romania
}

\begin{abstract}
Ten indeterminate tomato cultivars differing in fruit shape and typology, grown simultaneously in a greenhouse from Oltenia (Southwestern Romania) and harvested at red ripe stage, were investigated for the contents in ascorbic acid, lycopene, $\beta$-carotene, total phenolics, minerals ( $\mathrm{K}, \mathrm{Na}, \mathrm{Ca}$ and $\mathrm{Mg}$ ) and trace elements ( $\mathrm{Fe}, \mathrm{Cu}, \mathrm{Mn}, \mathrm{Cr}, \mathrm{Zn}$ and $\mathrm{B})$. In addition, their antioxidant activities were determined. Significant differences were found among tomato cultivars in all studied antioxidant compounds, as well as in the antioxidant activity. Ascorbic acid ranged from 91.9 to $329.7 \mathrm{mg} \mathrm{kg}^{-1} \mathrm{fw}$, lycopene ranged from 19.7 to $49.0 \mathrm{mg} \mathrm{kg}^{-1} \mathrm{fw}$, while total phenolic compounds varied between 300.2 and $557.8 \mathrm{mg} \mathrm{kg}^{-1} \mathrm{fw}$. Antioxidant activity ranged from $0.81 \mathrm{mmol} \mathrm{Trolox} \mathrm{kg}^{-1} \mathrm{fw}$ to 1.74 mmol Trolox kg ${ }^{-1} \mathrm{fw}$ and it was significantly correlated to total phenolics content $(r=0.91 ; p<0.05)$. The cocktail type cultivar 'Tiger' and the cherry type cultivar 'Belle' proved to be the most powerful in antioxidant activity and phenolic compounds while the rectangular plum shaped cultivar 'Porto' recorded the highest average lycopene content. A valuable cultivar proved to be the brownish red 'Sacher' which registered among the highest contents of phenolics, lycopene and ascorbic acid. Mineral and trace elements contents were also significantly affected by cultivars. Values recorded for $\mathrm{K}$, Ca and $\mathrm{Mg}$ ranged from 2139.6 to $3056.9 \mathrm{mg} \mathrm{kg}^{-1}, 137.7$ to $325.8 \mathrm{mg} \mathrm{kg}{ }^{-1}$ and 27.3 to $168.7 \mathrm{mg} \mathrm{kg}^{-1}$ respectively.
\end{abstract}

Keywords: antioxidant activity, ascorbic acid, carotenoids, minerals, phenolics, tomatoes

\section{Introduction}

Tomato (Solanum lycopersicum L.) is a horticultural crop of great interest, being widely consumed either fresh or processed in products such as tomato juice, soup, paste, puree, ketchup, sauce and salsa (Helyes et al., 2009; Ray et al., 2011).

Among the most prominent phytochemicals in tomatoes are the carotenoids, of which lycopene is the most abundant in the ripened fruit, accounting for approximately $80-90 \%$ of the total pigments (Hernández et al., 2007; Helyes et al., 2009). Besides lycopene, tomatoes also contain $\alpha-, \beta-, \gamma-, \delta$-carotene, zeaxanthin and lutein and also neurosporene, phytoene, and phytofluene (Capanoglu et al., 2010; Ray et al., 2011).

Lycopene mainly accumulates in the final period of ripening, giving the fruit its attractive red color although its content is not linearly related to color changes. The lycopene pigment has attracted much interest among researchers because of its biological and physicochemical properties, especially related to its effect as a natural antioxidant and its various benefits for human health (Hernández et al., 2007). Lycopene as well as $\beta$-carotene are apparently the main tomato microconstituents responsible for the ef- fect of tomato products on antioxidant status (Ray et al., 2011)

Tomatoes and tomato products are the primary suppliers of lycopene to the human diet, at least $85 \%$ of our dietary lycopene coming from these foods, the remainder being obtained from other dietary sources such as apricots, pink grapefruit, watermelon, guava, and papaya (Capanoglu et al., 2010; Radzevičius et al., 2009). Of all the carotenoid pigments, lycopene is not only the most abundant but also is the most efficient free radical scavenger with a capacity found to be more than twice that of $\beta$-carotene. Lycopene in tomato seems also to be more stable to changes occurring during peeling and juicing than the other carotenoids (Capanoglu et al., 2010).

Tomatoes are also a concentrated source of phenolic compounds, such as flavonoids and hydroxycinnamic acid derivatives, containing $98 \%$ of the total flavonols in tomato skin as conjugated forms of quercetin and kaempferol (Hernández et al., 2007; Ray et al. 2011). The flavanone naringenin is present in small quantities in tomatoes in its conjugated form. Many of these phytochemicals present in tomatoes have antioxidant properties and in combination with lycopene may contribute to the numerous health benefits (Ray et al., 2011). 
Tomatoes contain a multitude of vitamins and minerals that act to support human health. They are an excellent source of vitamins C, E, B6, folic acid, niacin, potassium, and trace elements, i.e. selenium, copper, manganese and zinc, which are cofactors of antioxidant enzymes (Borguini and Da Silva Torres, 2009; Luthria et al., 2006). It is assumed that these trace elements play a key role in the protection mechanisms by scavenging free radicals (Fernández-Ruiz et al., 2011).

The vitamin $\mathrm{C}$ content of fresh tomatoes depends on the variety and the cultivation conditions (Adalid et al., 2010). Vitamin $\mathrm{E}$ in tomatoes is predominantly represented by $\alpha$-tocopherol. Like lycopene, vitamin E belongs to the lipophilic antioxidant fraction of the tomato fruit and has been linked to positive effects on human health (Capanoglu et al., 2010). These tomato antioxidants have an important role in chronic disease prevention, including cancer, neurodegenerative diseases, cardiovascular disease, asthma, and cataract and also in improving the immune function (Fernández-Ruiz et al., 2011). All these have led tomatoes and processed tomato products to be a key component of the Mediterranean diet, which is recognized as being particularly healthy and strongly associated with a reduced risk of chronic degenerative diseases (FernándezRuiz et al., 2011; Pinela et al., 2012; Ray et al., 2011).

The chemical composition of the fruit depends on genetics, environmental factors (temperature, light, water and nutrient availability, air composition), agricultural techniques (varieties, plant growth regulators, ripening stage at harvest, training and irrigation system), and on post-harvest storage conditions (Borguini and Da Silva Torres, 2009; Maršić et al., 2011; Vinkovic Vrcek et al., 2011). Nevertheless lycopene content is mainly determined by the genetics of the variety being grown. According to Kuti and Konuru (2005) lycopene content varied significantly among the tomato varieties, with cherry tomato types having the highest lycopene content.

The nutritional importance of tomato indicates that it is necessary to formulate breeding programme and to develop cultivars rich in antioxidant compounds, process- ing traits with high quality of fruit as well as yield (Dar and Sharma, 2011). New tomato varieties with improved nutritional content and potential health benefits are being developed. As a result, at present, there is a large number of tomato cultivars with a wide range of morphological and sensorial characteristics which determine their use (Fernández-Ruiz et al., 2011; Pinela et al., 2012). Therefore it is becoming increasingly important to assess their nutritional value in terms of content.

The present investigation was carried out to evaluate ten newely evolved tomato hybrids grown simultaneously in the same greenhouse from Oltenia region (Southwestern Romania), for the content of total dry matter, soluble solids, titratable acidity, total phenolics, lycopene, $\beta$-carotene, ascorbic acid, mineral ( $\mathrm{Na}, \mathrm{K}, \mathrm{Ca}, \mathrm{Mg}$ ) and trace elements (Fe, Mn, Cu, Cr, Zn, B) as well for the antioxidant properties.

\section{Materials and methods}

\section{Plant material}

Ten indeterminate tomato F1 hybrids ('Antalya', 'Belle', 'Cemile', 'Izmir', 'Lorely', 'Plumty, 'Porto', 'Sacher', 'Tiger', 'Vanessa') differing in fruit typology (round, elongated, cherry, cocktail) were considered for analysis (Tab. 1). All plants from each tomato cultivar were grown in cambic chernozem at Rusanesti, Olt district $\left(43^{\circ} 56^{\prime} \mathrm{N}, 24^{\circ} 36^{\prime} \mathrm{E}\right)$, in an unheated greenhouse covered with polymeric film. Date of planting to the greenhouse was April 10 th while plant density was 4.7 plants $\mathrm{m}^{-2}$. During the growing season all cultivation procedures (nutrition supply, irrigation and plant protection) were conducted according to technological expectations. The plants were fertilized with nutrient solution of MAP (12-61-0) through irrigation water until blossom, Polyfeed 19-19-19 (0.5\%), three applications up to fruit formation and Multi-K (potassium nitrate) from first ripening until end of the crop cycle. Plant protection included treatments with insecticides such as Mospilan, and fungicides such as Sumilex and Dithane.

Tab. 1. Main characteristics of the Solanum lycopersicum cultivars evaluated

\begin{tabular}{|c|c|c|c|c|c|c|}
\hline Cultivar & Color mature & Shape & $\begin{array}{c}\text { Fruit height } \\
(\mathrm{mm})\end{array}$ & $\begin{array}{c}\text { Fruit diameter } \\
(\mathrm{mm})\end{array}$ & $\begin{array}{l}\text { Index of } \\
\text { fruit shape }\end{array}$ & $\begin{array}{c}\text { Average weight } \\
\text { (g) }\end{array}$ \\
\hline 'Antalya' & red & round & $51.48^{\text {bcd }}$ & $61.32^{c}$ & $0.84^{\mathrm{abc}}$ & $111.16^{\mathrm{cd}}$ \\
\hline 'Belle' & red & cherry & $26.54^{\mathrm{a}}$ & $28.52^{\mathrm{a}}$ & $0.91^{\mathrm{bc}}$ & $12.12^{\mathrm{a}}$ \\
\hline 'Cemile' & red & round & $50.04^{b}$ & $62.49^{c}$ & $0.79^{a}$ & $105.72^{\mathrm{cd}}$ \\
\hline 'Izmir' & red & round & $56.86^{\mathrm{bcd}}$ & $69.36^{\mathrm{d}}$ & $0.80^{\mathrm{ab}}$ & $141.88^{d}$ \\
\hline 'Lorely' & red & round & $53.74^{\mathrm{bc}}$ & $59.13^{c}$ & $0.90^{\mathrm{bc}}$ & $100.87^{b c}$ \\
\hline 'Plumty' & red & ellipsoid & $72.54^{\mathrm{c}}$ & $47.96^{\mathrm{b}}$ & $1.50^{\mathrm{c}}$ & $82.3^{b c}$ \\
\hline 'Porto' & red & plum, rectangular & $56.18^{c d}$ & $49.86^{\mathrm{b}}$ & $1.07^{\mathrm{d}}$ & $74.16^{\mathrm{bc}}$ \\
\hline 'Sacher' & brownish red & round & $48.46^{\mathrm{b}}$ & $52.03^{b}$ & $0.92^{c}$ & $67.90^{\mathrm{b}}$ \\
\hline 'Tiger' & bi-colored, dark red and green & cocktail & $31.14^{\mathrm{a}}$ & $32.61^{a}$ & $0.95^{c}$ & $17.96^{\mathrm{a}}$ \\
\hline 'Vanessa' & red & round & $62.06^{\mathrm{d}}$ & $68.62^{d}$ & $0.89^{a b c}$ & $151.34^{\mathrm{d}}$ \\
\hline
\end{tabular}

*Values in the same column followed by different superscript letters are significantly different at $p<0.05$ 
138

\section{Sampling}

Three tomatoes selected from each sample were washed, blotted with a paper towel and cut into halves, the seeds were removed and the pericarp and mesocarp were ground to a homogeneous puree in a blender for $1 \mathrm{~min}$. The samples were stored at $-18^{\circ} \mathrm{C}$ until analysis. Experiments were executed in four repetitions, and the results were expressed as average \pm standard error of average of repetitions.

\section{Analytical methods}

Dry matter content (\%) was determined gravimetrically by drying $5 \mathrm{~g}$ tomato homogenate to a constant weight at $105^{\circ} \mathrm{C}$. Soluble solids content (\%) was determined with a digital refractometer after tomato homogenate clarification by centrifugation ( $4000 \mathrm{rpm}, 10 \mathrm{~min}$ ) and expressed as a percentage. Titratable acidity (\% as citric acid) was determined by titrating the water extract of tomato homogenate with $0.1 \mathrm{~N}$ sodium hydroxide $(\mathrm{NaOH})$ to an end point of neutral $\mathrm{pH}$ (8.1) with phenolphthalein as colorimetric indicator.

\section{Determination of antioxidant compounds}

\section{Carotenoids}

Determination was based on a spectrophotometric analysis following the method developed by Nagata and Yamashita (1992) for the simultaneous determination of chlorophyll and carotenoids in tomato fruit. The samples were thawed in the dark in a refrigerator at $4^{\circ} \mathrm{C}$ to avoid carotenoid oxidation. Sixteen mililiters of acetone-hexane (4:6) solvent were added to $1.0 \mathrm{~g}$ of tomato homogenate and mixed in a test-tube. Automatically, two phases separated, and an aliquot was taken from the upper solution for measurement of optical density at 663, 645, 505, and $453 \mathrm{~nm}$ in a spectrophotometer (Varian Cary 50 UV-Vis, Varian Co., USA). Lycopene and $\beta$-carotene contents were calculated according to the equations: Lycopene ( $\mathrm{mg}$ $100 \mathrm{~mL}^{-1}$ of extract $)=-0.0458 \times \mathrm{A}_{663}+0.204 \times \mathrm{A}_{645}+$ $0.372 \times \mathrm{A}_{505}-0.0806 \times \mathrm{A}_{453} ; \beta$-Carotene $\left(\mathrm{mg} 100 \mathrm{~mL}^{-1}\right.$ of extract $)=0.216 \times \mathrm{A}_{663}-1.22 \times \mathrm{A}_{645}-0.304 \times \mathrm{A}_{505}+0.452$ $\times \mathrm{A}_{453}$. Lycopene and $\beta$-carotene were finally expressed as $\mathrm{mg} \mathrm{kg}{ }^{-1}$ fw.

\section{Ascorbic acid}

Ascorbic acid was extracted and analyzed by reversedphase HPLC. Frozen tomato homogenate $(5 \mathrm{~g})$ was mixed and diluted to $100 \mathrm{~mL}$ with $0.1 \mathrm{~N} \mathrm{HCl}$. After 30 minutes the extraction solution was centrifuged at $4200 \mathrm{rpm}$ for 10 minutes. The supernatant was filtered through $0.2 \mu \mathrm{m}$ pore size filter.

HPLC-DAD analysis was performed on a Finningan Surveyor Plus system (Thermo Electron Corporation, San Jose, CA, USA) coupled with a photodiode array detector (DAD) set at $245 \mathrm{~nm}$. The separation was performed using a Hypersil Gold aQ column $(25 \mathrm{~cm} \times 4.6 \mathrm{~mm})$ with a particle size of $5 \mu \mathrm{m}$ while a $50 \mathrm{mM}$ water solution of
$\mathrm{KH}_{2} \mathrm{PO}_{4}$ buffer adjusted to $\mathrm{pH} 2.8$ with ortho-phosphoric acid was used as the mobile phase. The column temperature was kept at $10^{\circ} \mathrm{C}$ and the flow rate at $0.7 \mathrm{~mL} \mathrm{~min}^{-1}$. All the results were expressed in $\mathrm{mg} \mathrm{kg}^{-1} \mathrm{fw}$. Acetonitrile was HPLC grade (Merck, Germany) while potassium dihydrogen orthophosphate and phosphoric acid were of analytical purity (Sigma-Aldrich, Germany). Ultrapure water was obtained from a Milli-Q water purification system (TGI Pure Water Systems, USA).

\section{Total phenolic content}

Total phenolic content was assessed by using the FolinCiocalteau phenol reagent method (Singleton and Rossi, 1965). Folin Ciocalteu reagent (2N, Merk), gallic acid (99\% purity, Sigma), anhydrous sodium carbonate (99\% purity, Sigma) were used.

Samples (3 g of tomato homogenate) were extracted with $5 \mathrm{~mL}$ methanol in an ultrasonic bath for $45 \mathrm{~min}$ at ambient temperature. After extraction, the samples were centrifuged for $5 \mathrm{~min}$ at $4200 \mathrm{rpm}$. Supernatants were filtered through polyamide membranes with pore diameter of $0.45 \mu \mathrm{m}$ and stored at a temperature of $-20^{\circ} \mathrm{C} .100 \mu \mathrm{L}$ of each tomato methanolic extract were mixed with $5 \mathrm{~mL}$ of distilled water and $500 \mu \mathrm{L}$ of Folin-Ciocalteau reagent. After $30 \mathrm{sec}$ to $8 \mathrm{~min}, 1.5 \mathrm{~mL}$ of sodium carbonate $(20 \%$ w/v) was added. The reaction mixture was diluted with distilled water to a final volume of $10 \mathrm{~mL}$. The same procedure was also applied to the standard solutions of gallic acid. The absorbance at $765 \mathrm{~nm}$ of each mixture was measured on a Varian Cary 50 UV spectrophotometer (Varian Co., USA) after incubation for $30 \mathrm{~min}$ at $40^{\circ} \mathrm{C}$. Results were expressed as mg of gallic acid equivalents (GAE) $\mathrm{kg}^{-1}$ fw.

\section{Determination of antioxidant activity}

Relative antioxidant activity was measured in methanol tomato extracts using the DPPH (2,2-diphenyl-1-picrylhydrazyl) assay. Methanol (Merck, Germany), 2,2-diphenyl-1-picrylhydrazyl (DPPH) (Sigma-Aldrich, Germany), and 6-hydroxy-2,5,7,8-tetramethylchroman-2-carboxylic acid (Trolox) (Merck, Germany) were employed. The extraction of samples was made according to the same protocol as described for total phenolic content. The free radical scavenging ability of the extracts against DPPH free radical was evaluated as described by Oliveira $e t$ al. (2008), with some modifications. Briefly, each methanol tomato extract $(50 \mu \mathrm{L})$ was mixed with $3 \mathrm{~mL}$ of a $0.004 \%$ (v/v) DPPH methanolic solution. The mixture was incubated for $30 \mathrm{~min}$ at room temperature in the dark and the absorbance was measured at $517 \mathrm{~nm}$ on Varian Cary 50 UV-Vis spectrophotometer. The DPPH free radical scavenging ability was subsequently calculated with respect to the Trolox (6-hydroxy-2,5,7,8-tetramethylchroman-2carboxylic acid), which was used as a standard reference to convert the inhibition capability of each extract solution to the mmol Trolox equivalent antioxidant activity 
$\mathrm{L}^{-1}$. The radical was freshly prepared and protected from the light. A blank control of methanol/water mixture was run in each assay. All assays were conducted in triplicate. Results were expressed in mmol Trolox kg-1 fw.

\section{Determination of mineral and trace elements content}

Sodium $(\mathrm{Na})$, calcium $(\mathrm{Ca})$, magnesium $(\mathrm{Mg})$, potassium $(\mathrm{K})$, iron $(\mathrm{Fe})$, manganese $(\mathrm{Mn})$, copper $(\mathrm{Cu})$, zinc $(\mathrm{Zn})$, chromium $(\mathrm{Cr})$, and boron $(\mathrm{B})$ were determined by microwave digestion followed by inductively coupled plasma mass spectrometry (ICP-MS). Samples of approximately $2.0 \mathrm{~g}$ tomato homogenate were weighed in TFM vessels, over that $5 \mathrm{~mL}$ nitric acid $65 \%$ and $2 \mathrm{~mL}$ hydrogen peroxide $30 \%$ were added. The vessels were then closed and mounted in special outer vessels and heated at $180^{\circ} \mathrm{C}$ for $20 \mathrm{~min}$ in the Milestone digestion microwave system. Reagent blanks were included in each series of digestions. After digestion was completed, the clear, colourless solution was transferred into a $50 \mathrm{~mL}$ volumetric flask and make up to the mark with ultrapure water. The sample solutions were stored in polyethylene vials at $6^{\circ} \mathrm{C}$ until analysis. An Elan 9000 inductively coupled plasma mass spectrometer (Perkin Elmer Sciex, Canada) equipped with Meinhard nebulizer and Scott-type double-pass spray chamber was used throughout. The results were expressed in $\mathrm{mg} \mathrm{kg}^{-1}$ fw.

\section{Statistical analyses}

Data were evaluated by one-way analysis of variance (ANOVA) using Statgraphics Centurion XVI software (StatPoint Technologies, Warrenton, VA, USA). Differences in content levels among the cultivars were estimated with a multiple range test using the least significant difference (LSD) at $p<0.05$.

\section{Results and discussion}

Data on dry matter content, soluble solids content and titratable acidity are shown in Tab. 2. Dry matter content ranged between $5.88 \%$ in the ellongated tomato cultivar ('Porto') and $10.04 \%$ in the cherry-type tomato cultivar ('Belle'). These results were close to the values presented by Gupta et al. (2011) who reported 5.55\% and 7.73\% for two newly developed tomato genotypes, or by Pinela et al. (2012) who reported 6.3\% to $9.37 \%$ dry matter content in four tomato varieties grown in Northeastern Portugal.

The total soluble solids were determined between $4.98 \%$ and $8.38 \%$ in the analysed tomato cultivars. Significantly $(p<0.05)$ higher amounts of total soluble solids were found in the fruits of 'Tiger' (8.38\%) and 'Belle' (8.15\%) cherry type cultivars, followed by 'Cemile' (7.98\%) while the lowest levels were found in 'Vanessa' (4.98\%) and 'Porto' (5.35\%) tomatoes. Gupta et al. (2011) reported 5.1\% and $5.5 \%$ total soluble solids in the fruits of two tomato genotypes.
The level of acidity in tomato fruits is an important parameter associated with sensory attributes like flavor and astringency. Titratable acidity varied significantly between $0.10 \%$ ('Vanessa') and $0.41 \%$ ('Plumty'). Similar results were reported by other authors in studies of different tomatoes genotypes (Olaiya et al., 2010; Owusu et al., 2012). However, some of the data reported in the literature for ripened tomatoes were slightly higher than our data (Geboloğlu et al., 2011; Gupta et al., 2011). The cherry type cultivar 'Belle' registered a titratable acidity of $0.32 \%$, result in good agreement with $0.35 \%$ titratable acidity reported by Žnidarčič et al. (2010) for the fruits of the same cultivar.

Antioxidants such as ascorbic acid, carotenoids and phenolics were determined and the results are provided in Tab. 2. There were significant differences in the amount of ascorbic acid in the different cultivars of tomatoes studied, and the highest concentration was found in the samples of the so-called cocktail tomato cultivar 'Tiger' $(329.7 \mathrm{mg}$ $\left.\mathrm{kg}^{-1}\right)$ followed by the cultivar of cherry type tomato 'Belle' $\left(227.5 \mathrm{mg} \mathrm{kg}^{-1}\right)$. Other two cultivars, 'Sacher' and 'Lorely' have shown contents slightly above the commonly accepted average level in the commercial tomato $\left(200 \mathrm{mg} \mathrm{kg}^{-1}\right)$ while 'Vanessa' and 'Plumty' presented nearly half of this content (91.9 and $95.8 \mathrm{mg} \mathrm{kg}^{-1} \mathrm{fw}$ respectively). Pinela $e t$ al. (2012) found contents of ascorbic acid between 108.6 and $185.6 \mathrm{mg} \mathrm{kg}^{-1} \mathrm{fw}$, Dar and Sharma (2011) found ascorbic acid content in the range $197.7-378 \mathrm{mg} \mathrm{kg}^{-1} \mathrm{fw}$ while Frenich et al. (2005), using liquid chromatography with mass spectrometry detection, determined 97 to $180 \mathrm{mg}$ $\mathrm{kg}^{-1}$ ascorbic acid in different tomato cultivars. Likewise, our results are in agreement with those of Adalid et al. (2010) and Vinkovic Vrcek et al. (2011) who concluded that smaller fruits (cherry type tomatoes) have generally higher vitamin $\mathrm{C}$ content.

The results on lycopene content show a significant variation among the different cultivars of tomato (Tab. 2), ranging from $19.7 \mathrm{mg} \mathrm{kg}^{-1} \mathrm{fw}$ to $49.0 \mathrm{mg} \mathrm{kg}^{-1} \mathrm{fw}$. Data corresponds to earlier study made by Dar and Sharma (2011) on 60 diverse genotypes of tomato, who reported lycopene content between 19.5 and $46.2 \mathrm{mg} \mathrm{kg}^{-1} \mathrm{fw}$. Kuti and Konoru (2005) also found the total lycopene content in fresh market tomato varieties grown in the greenhouse ranging from $5.7 \mathrm{mg} \mathrm{kg}^{-1}$ to $47.8 \mathrm{mg} \mathrm{kg}^{-1} \mathrm{fw}$ while Frenich et al. (2005) determined 8 to $37 \mathrm{mg} \mathrm{kg}^{-1}$ lycopene using liquid chromaography with mass spectrometry detection. Besides, the average lycopene content of raw tomatoes has been reported at $30 \mathrm{mg} \mathrm{kg}^{-1}$ (Adalid et al., 2010; Kuti and Konuru, 2005). Significant differences $(p<0.05)$ were found among the average lycopene content of examined cultivars. The plum shaped cultivar 'Porto' recorded the highest average lycopene content of all $\left(49 \mathrm{mg} \mathrm{kg}^{-1} \mathrm{fw}\right)$. Aherne et al. (2009) reported also that Spanish plum tomatoes had the highest $(p<0.05)$ lycopene content when compared to cherry, cherry-on-the-vine, and round tomatoes while Muratore et al. (2005) reported that five out of 
Tab. 2. Chemical characteristics, contents of antioxidant compounds and antioxidant activity of the Solanum lycopersicum cultivars evaluated

\begin{tabular}{|c|c|c|c|c|c|c|c|c|}
\hline Cultivar & $\begin{array}{l}\text { Dry } \\
\text { matter } \\
(\%)\end{array}$ & $\begin{array}{l}\text { Soluble } \\
\text { solids } \\
(\%)\end{array}$ & $\begin{array}{c}\text { Titratable } \\
\text { acidity } \\
\text { (\% as citric acid })\end{array}$ & $\begin{array}{c}\text { Ascorbic } \\
\text { acid } \\
\left(\mathrm{mg} \mathrm{kg}^{-1}\right)\end{array}$ & $\begin{array}{c}\beta \text {-carotene } \\
\left(\mathrm{mg} \mathrm{kg}^{-1}\right)\end{array}$ & $\begin{array}{l}\text { Lycopene } \\
\left(\mathrm{mg} \mathrm{kg}^{-1}\right)\end{array}$ & $\begin{array}{l}\text { Total phenolics } \\
\left(\mathrm{mg} \mathrm{GAE} \mathrm{kg}^{-1}\right)\end{array}$ & $\begin{array}{c}\text { Antioxidant } \\
\text { activity } \\
\left(\text { mmol Trolox } \mathrm{kg}^{-1}\right)\end{array}$ \\
\hline 'Antalya' & $7.96 \pm 0.38^{d}$ & $6.98 \pm 0.46^{\mathrm{cd}}$ & $0.19 \pm 0.02^{\text {cd }}$ & $146.0 \pm 2.8^{\mathrm{cd}}$ & $8.2 \pm 0.8^{\mathrm{abc}}$ & $31.8 \pm 2.4^{b}$ & $300.2 \pm 4.1^{\mathrm{a}}$ & $0.87 \pm 0.2^{a}$ \\
\hline 'Belle' & $10.04 \pm 0.25^{\mathrm{a}}$ & $8.15 \pm 0.58^{c}$ & $0.32 \pm 0.03^{\mathrm{c}}$ & $227.5 \pm 6.9^{c}$ & $12.8 \pm 1.4^{\mathrm{d}}$ & $20.2 \pm 1.8^{\mathrm{a}}$ & $557.8 \pm 10.2^{\mathrm{c}}$ & $1.62 \pm 0.2^{c}$ \\
\hline 'Cemile' & $8.63 \pm 0.18^{c}$ & $7.98 \pm 0.74^{\mathrm{dc}}$ & $0.16 \pm 0.02^{\mathrm{bc}}$ & $153.2 \pm 5.6^{d}$ & $7.9 \pm 0.6^{\mathrm{abc}}$ & $23.5 \pm 3.0^{\mathrm{a}}$ & $329.6 \pm 11.3^{b}$ & $0.99 \pm 0.1^{\mathrm{ab}}$ \\
\hline 'Izmir' & $6.08 \pm 0.22^{f}$ & $5.68 \pm 0.31^{\mathrm{ab}}$ & $0.13 \pm 0.01^{\mathrm{ab}}$ & $114.8 \pm 4.4^{b}$ & $7.2 \pm 0.9^{\mathrm{ab}}$ & $21.0 \pm 2.8^{\mathrm{a}}$ & $312.2 \pm 9.8^{a}$ & $1.05 \pm 0.1^{\mathrm{ab}}$ \\
\hline 'Lorely' & $7.78 \pm 0.21^{\mathrm{d}}$ & $7.00 \pm 0.75^{\mathrm{cd}}$ & $0.22 \pm 0.01^{\mathrm{d}}$ & $218.9 \pm 7.1^{\mathrm{c}}$ & $6.4 \pm 1.0^{\mathrm{a}}$ & $31.2 \pm 2.6^{b}$ & $337.3 \pm 6.6^{\mathrm{bc}}$ & $0.81 \pm 0.1^{\mathrm{a}}$ \\
\hline 'Plumty' & $6.70 \pm 0.33^{\mathrm{c}}$ & $6.20 \pm 0.78^{b c}$ & $0.41 \pm 0.02^{f}$ & $91.9 \pm 3.3^{\mathrm{a}}$ & $8.5 \pm 0.8^{\mathrm{bc}}$ & $32.4 \pm 2.8^{b}$ & $351.4 \pm 8.9^{c}$ & $0.87 \pm 0.1^{\mathrm{a}}$ \\
\hline 'Porto' & $5.88 \pm 0.11^{f}$ & $5.35 \pm 0.62^{\mathrm{ab}}$ & $0.29 \pm 0.02^{\mathrm{c}}$ & $137.6 \pm 6.6^{c}$ & $9.3 \pm 1.1^{\mathrm{c}}$ & $49.0 \pm 4.1^{c}$ & $408.8 \pm 12.0^{\mathrm{d}}$ & $1.23 \pm 0.3^{b}$ \\
\hline 'Sacher' & $6.98 \pm 0.21^{\mathrm{c}}$ & $6.23 \pm 0.48^{b c}$ & $0.19 \pm 0.01^{\mathrm{cd}}$ & $225.4 \pm 8.8^{c}$ & $16.2 \pm 1.0^{c}$ & $35.8 \pm 3.3^{b}$ & $35.05 \pm 0.44^{c}$ & $1.08 \pm 0.1^{\mathrm{ab}}$ \\
\hline 'Tiger' & $9.19 \pm 0.26^{\mathrm{b}}$ & $8.38 \pm 0.46^{c}$ & $0.13 \pm 0.01^{\mathrm{ab}}$ & $329.7 \pm 11.2^{f}$ & $20.6 \pm 1.8^{f}$ & $44.6 \pm 2.8^{c}$ & $557.2 \pm 11.0^{c}$ & $1.74 \pm 0.2^{c}$ \\
\hline 'Vanessa' & $5.92 \pm 0.15^{f}$ & $4.98 \pm 0.68^{\mathrm{a}}$ & $0.10 \pm 0.02^{\mathrm{a}}$ & $95.8 \pm 3.0^{\mathrm{a}}$ & $6.5 \pm 0.6^{\mathrm{a}}$ & $19.7 \pm 2.2^{\mathrm{a}}$ & $337.9 \pm 7.8^{\mathrm{bc}}$ & $0.96 \pm 0.2^{\mathrm{ab}}$ \\
\hline
\end{tabular}

* Values in the same column followed by different superscript letters are significantly different at $p<0.05$

six Italian grown plum tomato cultivars contained greater amounts of lycopene than cherry tomatoes. These nutritional characteristics explain why in recent years there has been an increased demand for this tomato variety. Fruits of the cocktail type cultivar 'Tiger' presented the second average lycopene content $\left(44.6 \mathrm{mg} \mathrm{kg}^{-1}\right)$ followed by the brownish red cultivar 'Sacher' $\left(35.8 \mathrm{mg} \mathrm{kg}^{-1} \mathrm{fw}\right)$. The high contents of lycopene of these remarkable cultivars contribute to the attractive appearance of the fruits, knowing that lycopene is the predominant carotenoid in red ripe tomatoes and the main responsible for their red colour. The cherry type cultivar 'Belle' presented lower lycopene content although cherry tomato types usually showed a higher lycopene content than common tomatoes (Adalid et al., 2010; Kuti and Konoru, 2005).

The 'Tiger' tomatoes presented also the highest content of $\beta$-carotene $\left(20.6 \mathrm{mg} \mathrm{kg}^{-1} \mathrm{fw}\right)$ followed by the 'Sacher' tomatoes $\left(16.2 \mathrm{mg} \mathrm{kg}^{-1} \mathrm{fw}\right.$ ) while the fruits of cherry type cultivar 'Belle' presented a $\beta$-carotene content of 12.8 $\mathrm{mg} \mathrm{kg}^{-1} \mathrm{fw}$. Like Adalid et al. (2010) who found the highest content of $\beta$-carotene $\left(13 \mathrm{mg} \mathrm{kg}^{-1}\right)$ in the fruits of a cherry type cultivar, other workers also reported that cherry tomatoes are richest in $\beta$-carotene. The rest of the cultivars evaluated in the present work had $\beta$-carotene contents between 6.4 and $9.3 \mathrm{mg} \mathrm{kg}^{-1} \mathrm{fw}$, values in good agreement with previous studies (Adalid et al., 2010; Gupta et al., 2011).

Besides antioxidants lycopene, $\beta$-carotene and ascorbic acid, tomatoes also contain flavonoids and related phenolics. The main phenolic compounds found in tomato are the flavonols quercetin and kaempferol and the hydroxycinnamic acids, particularly the caffeic and chlorogenic acids (Vallverdú-Queralt et al., 2011). Total phenolic content ranged from $312.2 \mathrm{mg} \mathrm{GAE} \mathrm{kg}^{-1}$ to $557.8 \mathrm{mg} \mathrm{kg}^{-1}$. Significant differences in the mean values of total phenolic compounds were found between the cultivars of tomatoes considered, the cherry tomatoes 'Belle' and the cocktail tomatoes 'Tiger' showing the greatest contents $(557.8 \mathrm{mg}$ GAE kg-1 and $557.2 \mathrm{mg} \mathrm{GAE} \mathrm{kg}^{-1}$ respectively). Higher levels of total phenolic content in smaller tomatoes, compared to cultivars with larger fruits, are due to the higher skin to volume ratio of these varieties, which could enhance their phenolic content, particularly flavonols, since these compounds are mainly found in the skin (Maršić et al., 2011). The total phenolic concentrations found in this study were similar to those reported by other studies (Luthria et al., 2006; Hernández et al., 2007; Helyes et al., 2012; Martínez-Valverde et al., 2002).

Considering the content of antioxidant compounds, it is of great interest to determine the total antioxidant activity of the cultivars evaluated expressed by the capacity to scavenge the stable free radical DPPH. Antioxidant activities of tomatoes were found between 0.81 and $1.74 \mathrm{mmol}$ Trolox $\mathrm{kg}^{-1} \mathrm{fw}$ (Tab. 2), in agreement with the results found by other authors (Erge and Karadeniz, 2011). The data show that the antioxidant activities of two cultivars ('Tiger' and 'Belle') are significantly higher compared to the rest of cultivars.

Tomatoes can be considered as good sources of some mineral elements, some of them with antioxidant properties. Mineral content was significantly affected by cultivars (Tab. 3). Among macroelements, K (potassium) presented the highest concentration, ranging from $2139.6 \mathrm{mg} \mathrm{kg}^{-1}$ to $3056.9 \mathrm{mg} \mathrm{kg}^{-1}$, values similar with those reported by most authors (Costa et al., 2011; Fernández-Ruiz et al., 2011; Guil-Guerrero and Rebolloso-Fuentes, 2009). The 'Tiger' tomatoes showed the highest mean $\mathrm{K}$ content followed by 'Lorely' (3018.4 $\mathrm{mg} \mathrm{kg}^{-1}$ ) and 'Cemile' (3014.2 mg $\mathrm{kg}^{-1}$ ), with significant differences in relation to the rest of the cultivars. $\mathrm{Mg}$ (magnesium) contents ranged between $137.7 \mathrm{mg} \mathrm{kg}^{-1}$ and $325.8 \mathrm{mg} \mathrm{kg}^{-1}$, results higher than some previous reported data which do not exceed $220 \mathrm{mg} \mathrm{kg}^{-1}$ fw (Guil-Guerrero and Rebolloso-Fuentes, 2009; Costa et al., 2011; Hernández Suárez et al., 2007). Ca (calcium) content ranged between $27.3 \mathrm{mg} \mathrm{kg}^{-1}$ and $168.7 \mathrm{mg} \mathrm{kg}^{-1}$, results in good agreement with those reported by GuilGuerrero and Rebolloso-Fuentes (2009) and Geboloğlu et al. (2011) but lower than those reported by Costa et al. 
Tab. 3. Mineral and trace elements content of the Solanum lycopersicum cultivars evaluated $\left(\mathrm{mg} \mathrm{kg}^{-1} \mathrm{fw}\right)$

\begin{tabular}{|c|c|c|c|c|c|c|c|c|c|c|}
\hline Cultivar & $\mathrm{Ca}$ & $\mathrm{Mg}$ & $\mathrm{K}$ & $\mathrm{Na}$ & $\mathrm{Fe}$ & $\mathrm{Mn}$ & $\mathrm{Cu}$ & $\mathrm{Cr}$ & $\mathrm{Zn}$ & B \\
\hline 'Antalya' & $168.7 \pm 11.2 \mathrm{f}$ & $241.8 \pm 13.3^{c}$ & $2139.6 \pm 83.3^{a}$ & $166.1 \pm 5.6^{f}$ & $5.8 \pm 0.7^{b}$ & $1.3 \pm 0.2^{b c}$ & $2.0 \pm 0.4^{c}$ & $0.6 \pm 0.1^{b}$ & $6.8 \pm 0.1^{b}$ & $2.7 \pm 0.3^{\text {cd }}$ \\
\hline 'Belle' & $156.5 \pm 11.2^{f}$ & $218.3 \pm 9.4^{b}$ & $2817.8 \pm 69.8^{\mathrm{d}}$ & $103.6 \pm 6.7^{\mathrm{c}}$ & $9.7 \pm 1.0^{\mathrm{f}}$ & $1.8 \pm 0.3^{\mathrm{d}}$ & $1.9 \pm 0.4^{c}$ & $0.6 \pm 0.1^{\mathrm{b}}$ & $8.0 \pm 0.3^{\mathrm{d}}$ & $2.3 \pm 0.3^{b c}$ \\
\hline 'Cemile’ & $67.7 \pm 5.6^{\mathrm{bc}}$ & $325.8 \pm 15.5^{f}$ & $3014.2 \pm 114.5^{\mathrm{cf}}$ & $68.1 \pm 4.5^{\mathrm{b}}$ & $5.5 \pm 0.5^{\mathrm{ab}}$ & $1.7 \pm 0.3^{\mathrm{d}}$ & $2.0 \pm 0.3^{c}$ & $0.6 \pm 0.2^{b}$ & $6.2 \pm 0.1^{a}$ & $2.1 \pm 0.2^{b}$ \\
\hline 'Izmir' & $129.8 \pm 8.1^{\mathrm{c}}$ & $209.4 \pm 8.4^{\mathrm{b}}$ & $2826.5 \pm 96.6^{\mathrm{d}}$ & $42.5 \pm 3.4^{a}$ & $7.1 \pm 0.8^{c}$ & $1.0 \pm 0.1^{\mathrm{ab}}$ & $1.3 \pm 0.2^{\mathrm{ab}}$ & $0.4 \pm 0.1^{\mathrm{ab}}$ & $8.0 \pm 0.2^{\mathrm{d}}$ & $3.1 \pm 0.3^{\mathrm{dc}}$ \\
\hline 'Lorely' & $137.8 \pm 7.8^{c}$ & $285.1 \pm 12.3^{\mathrm{dc}}$ & $3018.4 \pm 57.8^{\text {ef }}$ & $69.2 \pm 5.9^{\mathrm{b}}$ & $6.3 \pm 0.8^{b c}$ & $1.3 \pm 0.1^{b c}$ & $1.6 \pm 0.2^{\mathrm{bc}}$ & $0.4 \pm 0.1^{\mathrm{ab}}$ & $6.2 \pm 0.1^{\mathrm{a}}$ & $2.1 \pm 0.2^{b}$ \\
\hline 'Plumty' & $60.5 \pm 5.3^{\mathrm{b}}$ & $253.8 \pm 11.1^{\mathrm{c}}$ & $2898.5 \pm 101.2^{\mathrm{de}}$ & $42.5 \pm 3.3^{a}$ & $5.9 \pm 0.5^{b}$ & $1.8 \pm 0.2^{\mathrm{d}}$ & $1.0 \pm 0.1^{\mathrm{a}}$ & $0.4 \pm 0.1^{\mathrm{ab}}$ & $6.8 \pm 0.2^{b}$ & $3.2 \pm 0.3^{\mathrm{de}}$ \\
\hline 'Porto' & $27.3 \pm 2.8^{a}$ & $305.1 \pm 13.8^{\mathrm{cf}}$ & $2827.9 \pm 68.8^{\mathrm{d}}$ & $39.5 \pm 2.2^{\mathrm{a}}$ & $8.7 \pm 0.8^{\mathrm{cf}}$ & $2.5 \pm 0.3^{c}$ & $1.9 \pm 0.2^{c}$ & $0.3 \pm 0.1^{\mathrm{a}}$ & $6.5 \pm 0.1^{\mathrm{ab}}$ & $3.0 \pm 0.3^{\mathrm{dc}}$ \\
\hline 'Sacher' & $80.1 \pm 8.9^{c}$ & $137.7 \pm 7.7^{\mathrm{a}}$ & $2481.0 \pm 44.4^{c}$ & $88.4 \pm 4.1^{\mathrm{d}}$ & $4.6 \pm 0.5^{a}$ & $0.7 \pm 0.1^{\mathrm{a}}$ & $0.9 \pm 0.1^{\mathrm{a}}$ & $0.3 \pm 0.1^{\mathrm{a}}$ & $7.7 \pm 0.3^{\mathrm{d}}$ & $1.3 \pm 0.2^{\mathrm{a}}$ \\
\hline 'Tiger' & $107.4 \pm 7.8^{\mathrm{d}}$ & $277.5 \pm 13.1^{\mathrm{d}}$ & $3056.9 \pm 99.8^{f}$ & $78.9 \pm 3.8^{c}$ & $8.4 \pm 0.6^{\mathrm{dc}}$ & $1.5 \pm 0.2^{\mathrm{cd}}$ & $1.7 \pm 0.3^{\mathrm{bc}}$ & $0.4 \pm 0.1^{\mathrm{ab}}$ & $7.3 \pm 0.2^{c}$ & $3.3 \pm 0.4^{\mathrm{c}}$ \\
\hline 'Vanessa' & $131.6 \pm 6.6^{\mathrm{c}}$ & $281.3 \pm 14.4^{\mathrm{d}}$ & $2301.3 \pm 63.4^{\mathrm{b}}$ & $41.1 \pm 2.8^{\mathrm{a}}$ & $7.4 \pm 0.5^{\mathrm{cd}}$ & $1.6 \pm 0.2^{\mathrm{cd}}$ & $1.1 \pm 0.2^{\mathrm{a}}$ & $0.6 \pm 0.2^{b}$ & $6.8 \pm 0.1^{\mathrm{b}}$ & $3.9 \pm 0.4^{\mathrm{f}}$ \\
\hline
\end{tabular}

*Values in the same column followed by different superscript letters are significantly different at $p<0.05$

(2011). 'Antalya' cultivar showed the highest mean of $\mathrm{Na}$ and $\mathrm{Ca}$ content and the lowest $\mathrm{K}$ content, with signifficant differences in relation to the rest of cultivars.

$\mathrm{Fe}$ (iron), Mn (manganese), $\mathrm{Cu}$ (copper), $\mathrm{Cr}$ (chromium), $\mathrm{Zn}$ (zinc) and B (boron) were the trace elements determined in our study (Tab. 3). Fe contents $\left(5.5 \mathrm{mg} \mathrm{kg}^{-1}\right.$ to $\left.9.7 \mathrm{mg} \mathrm{kg}^{-1}\right)$ were higher than those reported by Geboloğlu et al. (2011), but similar with those reported by Fernández-Ruiz et al. (2011). Also, values determined for Mn and $\mathrm{Zn}$ in our work are in agreement with those reported by other authors (Fernández-Ruiz et al., 2011; Geboloğlu et al., 2011; Hernández Suárez et al., 2007). With respect to copper, we found between $0.9 \mathrm{mg} \mathrm{kg}^{-1}$ and $2.0 \mathrm{mg} \mathrm{kg}^{-1}$ in the samples analysed, Hernández Suárez et al. (2007) reported 1.8 to $3.0 \mathrm{mg} \mathrm{kg}^{-1}$ while Fernández-Ruiz et al. (2011) found 4.3 to $7.4 \mathrm{mg} \mathrm{kg}^{-1}$. Note that tomatoes of the cherry type cultivar 'Belle' registered the highest contents of Fe (9.7 $\left.\mathrm{mg} \mathrm{kg}^{-1}\right), \mathrm{Mn}\left(1.7 \mathrm{mg} \mathrm{kg}^{-1}\right)$ and $\mathrm{Zn}\left(8.0 \mathrm{mg} \mathrm{kg}^{-1}\right)$, presenting also among the highest concentrations of $\mathrm{Ca}$, $\mathrm{Mg}$ and $\mathrm{Cu}$. On the other hand, tomatoes of 'Tiger' cultivar registered the highest content of $\mathrm{K}$ and significantly higher contents of $\mathrm{Mg}, \mathrm{Fe}, \mathrm{Cu}, \mathrm{Zn}$ and $\mathrm{B}$ as compared with the other cultivars. These results are in agreement with those of Costa et al. (2011) who found that cherry tomatoes presented the highest content of minerals amongst the studied tomato types.

\section{Conclusions}

Significant differences were detected among tomato cultivars in all studied antioxidant compounds, as well as in their antioxidant activity and mineral content. Since tomato cultivars were grown under the same agricultural, geographical and climatic conditions, the results showed the great variability in the bioactive component contents of tomato fruits and the significant influence of the cultivar on them. Lycopene and ascorbic acid content showed 1-2.5 fold and 1-3 fold variation on fresh weight basis, respectively.

Some of the evaluated cultivars are of great interest given their high content of bioactive compounds and antioxidant activity. Thus, the so-called cocktail tomato cultivar 'Tiger' and the cherry type cultivar 'Belle' proved to be the most powerful in antioxidant activity. The high antioxidant status of these two genotypes can be explained on the basis of their high phenolic, ascorbic acid and lycopene contents. A remarkable cultivar is 'Sacher', which, besides an interesting appearance given by its brownish red color resembling chocolate, revealed valuable nutritional composition, including among the highest contents of phenolics, carotenoids and ascorbic acid.

Mineral content was also significantly affected by cultivars. In this respect, the best-graded cultivars were 'Belle', with the highest contents of Fe, Mn and $\mathrm{Zn}$, and among the highest concentrations of $\mathrm{Ca}, \mathrm{Mg}$ and $\mathrm{Cu}$, and 'Tiger' with the highest content of $\mathrm{K}$ and significantly higher contents of $\mathrm{Mg}, \mathrm{Fe}, \mathrm{Cu}, \mathrm{Zn}$ and $\mathrm{B}$ as compared with the rest of cultivars.

\section{Acknowledgment}

This work benefited from the networking activities within the European funded COST ACTION FA1106 QualityFruit

\section{References}

Adalid AM, Roselló S, Nuez F (2010). Evaluation and selection of tomato accessions (Solanum section Lycopersicon) for content of lycopene, $\beta$-carotene and ascorbic acid. J Food Compos Anal 23(6):613-618.

Borguini RG, Da Silva Torres EAF (2009). Tomatoes and tomato products as dietary sources of antioxidants. Food Rev Int 25(4):313-325.

Capanoglu E, Beekwilder J, Boyacioglu D, De Vos RCH, Hall RD (2010). The effect of industrial food processing on potentially health-beneficial tomato antioxidants. Crit Rev Food Sci Nutr 50:919-930.

Costa F, Lurdes Baeta M, Saraiva D, Verissimo MT, Ramos F (2011). Evolution of mineral contents in tomato fruits during the ripening process after harvest. Food Anal Method 4:410-415.

Dar RA, Sharma JP (2011). Genetic variability studies of yield and quality traits in tomato (Solanum lycopersicum L.). Int J 
142

Plant Breed Genet 5:168-174.

Erge HS, Karadeniz F (2011). Bioactive compounds and antioxidant activity of tomato cultivars. Int J Food Prop 14(5):968-977.

Fernández-Ruiz V, Olives AI, Cámara M, Sánchez-Mata Mde C, Torija ME (2011). Mineral and trace elements content in 30 accessions of tomato fruits (Solanum lycopersicum L.,) and wild relatives (Solanum pimpinellifolium L., Solanum cheesmaniae L. Riley, and Solanum habrochaites S. Knapp \& D.M. Spooner). Biol Trace Elem Res 141:329-339.

Frenich AG, Torres MEH, Vega AB, Vidal JLM, Bolaños PP (2005). Determination of ascorbic acid and carotenoids in food commodities by liquid chromatography with mass spectrometry detection. J Agric Food Chem 53:7371-7376.

Geboloğlu N, Yılmaz E, Çakmak P, Aydın M, Kasap Y (2011). Determining of the yield, quality and nutrient content of tomatoes grafted on different rootstocks in soilless culture. Sci Res Essays 6(10):2147-2153.

Guil-Guerrero JL, Rebolloso-Fuentes MM (2009). Nutrient composition and antioxidant activity of eight tomato (Lycopersicon esculentum) varieties. J Food Compos Anal 22(2):123-129.

Gupta A, Kawatra A, Sehgal S (2011). Physical-chemical properties and nutritional evaluation of newly developed tomato genotypes. Afr J Food Sci Technol 2(7):167-172.

Helyes L, Lugasi A, Pogonyi Á, Pék Z (2009). Effect of variety and grafting on lycopene content of tomato (Lycopersicon Lycopersicum L. Karsten) fruit. Acta Aliment Hung 38(1):27-34.

Helyes L, Lugasi A, Pék Z (2012). Effect of irrigation on processing tomato yield and antioxidant components. Turk J Agric For 36:702-709.

Hernández M, Rodríguez E, Díaz C (2007). Free hydroxycinnamic acids, lycopene, and color parameters in tomato cultivars. J Agric Food Chem 55:8604-8615.

Hernández Suárez M, Rodríguez Rodríguez EM, Díaz Romero C (2007). Mineral and trace element concentrations in cultivars of tomatoes. Food Chem 104:489-499.

Kuti JO, Konuru HB (2005). Effects of genotype and cultivation environment on lycopene content in red-ripe tomatoes. J Sci Food Agric 85(12):2021-2026.

Luthria DL, Mukhopadhyay D, Krizek DT (2006). Content of total phenolics and phenolic acids in tomato (Lycopersicon esculentum Mill.) fruits as influenced by cultivar and solar UV radiation. J Food Compos Anal 19:771-777.

Maršić NK, Gašperlin L, Abram V, Budič M, Vidrih R (2011). Quality parameters and total phenolic content in tomato fruits regarding cultivar and microclimatic conditions. Turk J Agric For 35:185-194.
Martínez-Valverde I, Periago MJ, Provan G, Chesson A (2002). Phenolic compounds, lycopene and antioxidant activity in commercial varieties of tomato (Lycopersicum esculentum). J Sci Food Agr 82(3):323-330.

Muratore G, Licciardello F, Maccarone E (2005). Evaluation of the chemical quality of a new type of small-sized tomato cultivar, the plum tomato (Lycopersicon lycopersicum). Ital J Food Sci 17:75-81.

Nagata M, Yamashita I (1992). Simple method for simultaneous determination of chlorophyll and carotenoids in tomato fruit. J Jpn Soc Food Sci Technol 39:925-928.

Olaiya CO, Soetan KO, Ogunkolade NS (2010). Evaluation of the biochemical effects of auxins on nutritional quality of tomato (Solanum lycopersicon), genotype JM 94/47. Afr J Food Sci 4(2):041-045.

Oliveira I, Sousa A, Ferreira ICFR, Bento A, Estevinho L, Pereira JA (2008). Total phenols, antioxidant potential and antimicrobial activity of walnut (Juglans regia L.) green husks. Food Chem Toxicol 46:2326-2331.

Owusu J, Ma H, Wang Z, Amissah A (2012). Effect of drying methods on physicochemical properties of pretreated tomato (Lycopersicon esculentum Mill.) slices. Croat J Food Technol Biotechnol Nutr 7(1-2):106-111.

Pinela J, Barros L, Carvalho AM, Ferreira IC (2012). Nutritional composition and antioxidant activity of four tomato $(\mathrm{Ly}$ copersicon esculentum L.) farmer' varieties in Northeastern Portugal homegardens. Food Chem Toxicol 50(3-4):829834.

Radzevičius A, Karkleliene R, Viškelis P, Bobinas Č, Bobinaitė R, Sakalauskienè S (2009). Tomato (Lycopersicon esculentum Mill.) fruit quality and physiological parameters at different ripening stages of Lithuanian cultivars. Agron Res 7(2):S712-S718.

Ray RC, El Sheikha AF, Panda SH, Montet D (2011). Anti-oxidant properties and other functional attributes of tomato: An overview. Int J Fd Ferm Technol 1(2):139-148.

Vallverdú-Queralt A, Medina-Remón A, Martínez-Huélamo M, Jáuregui O, Andres-Lacueva C, Lamuela-Raventos RM (2011). Phenolic profile and hydrophilic antioxidant capacity as chemotaxonomic markers of tomato varieties. J Agric Food Chem 59:3994-4001.

Vinkovic Vrcek I, Samobor V, Bojic M, Medic-Saric M, Vukobratovic M, Erhatic R, Horvat D, Matotan Z (2011). The effect of grafting on the antioxidant properties of tomato (Solanum lycopersicum L.). Span J Agric Res 9(3):844-851.

Žnidarčič D, Ban D, Oplanić M, Karić L, Požrl T (2010). Influence of postharvest temperatures on physicochemical quality of tomatoes (Lycopersicon esculentum Mill.). J Food Agric Environ 8(1):21-25. 